\title{
Watkins' Law and the development of agglutinative inflections in Asia Minor Greek*
}

\author{
Mark Janse \\ Ghent University \\ mark.janse@ugent.be
}

\begin{abstract}
This paper interprets the agglutinative inflection of the copula and passive imperfect in Cappadocian and Bithynian as an adaptation of the Greek to the Turkish inflection on the basis of the third person singular in accordance with Watkins' Law. The first and second person plural forms of these agglutinative inflections add the corresponding Turkish personal suffixes to the Greek ones in the Cappadocian dialect of Semenderé and the Lycaonian dialect of Sílli. It is argued that the Turkish personal suffixes have been added because of the superficial formal similarity of the Greek ones with the corresponding Turkish temporal suffixes. The addition of the Turkish personal suffixes is interpreted as a case of triggered code-switching and hence as a violation of Poplack's Free Morpheme Constraint.
\end{abstract}

\section{Keywords}

agglutination; analogy; code-switching; contact-induced change; free-morpheme constraint; reanalysis; Watkins' Law

\section{Watkins' Law}

Watkins' Law is an hypothesis on the analogical reorganization of inflectional paradigms on the model of the third-person singular first stated by Calvert Watkins in his Indo-European Origins of the Celtic Verb (1962). Watkins' original statement runs as follows: "the development [...] or presence [...] of a zero ending in the $3 \mathrm{sg}$., and the spread of this $3 \mathrm{sg}$. form to other members of the paradigm" (1962: 96). Compare, for instance, the development of the 1-3sg forms of the verb 'to be' from Proto-Iranian to Persian (Fārsi) and from ProtoSlavic to Polish (Watkins 1962: 93f.):

* This is a thoroughly revised version of the paper originally presented at MGDLT3. I would like to thank Brian Joseph and two anonymous referees for their incisive remarks which have made me rethink the original order of arguments completely. Research for this revision was done while I was an Onassis Foreign Fellow at the National Institute for Research at Athens. 
(1)

Proto-Iranian
${ }^{*}$ as-mi
${ }^{*} a s-i$
${ }^{*} a s-t i$

Persian
hast-am
hast- $i$
hast- $\varnothing$

Proto-Slavic Polish

1 sg

$2 s g$

$3 \mathrm{sg}$

hast- $\varnothing$

$\begin{array}{ll}{ }^{*} e s-m i & \text { jest-em } \\ { }^{*} \text { es- } i & \text { jest-eś } \\ { }^{*} \text { es- } t i & \text { jest- } \varnothing\end{array}$

In both cases, the development of the modern forms is clear. Proto-IndoEuropean ${ }^{*} H_{l}$ es-ti developed into Proto-Iranian *as-ti, and further into Persian has- $t$, with secondary aspiration of word-initial /a/ and apocope of unstressed, word-final /i/. The modern form was reinterpreted as a stem with a zero ending: has- $t \rightarrow$ hast $-\varnothing$, and the rest of the paradigm is built on this new stem. It should be noted that the forms quoted here are those of the 'substantive' verb, not those of the enclitic copula, which have retained the older forms: $-a m,-i$, -ast (Windfuhr 1987: 530), cf. Avestan ah-mi, a-hi, as-ti (Beekes 1988: 163). The same analysis applies, mutatis mutandis, to the development of Polish jest$\varnothing$ from Proto-Slavic *es-ti: jes- $t \rightarrow$ jest- $\varnothing$. As in Persian, the enclitic copula has retained the original forms in Polish: $-(e) m$, $-(e) \dot{s},-\varnothing$ (Stone 1987: 361f.), cf. Old Church Slavonic jes-mŭ, jes-i, jes-tŭ (Lunt 2001: 137).

Watkins (1962) quotes many more examples, with reference to Benveniste (1946), who was the first to note the 'non-personality' of the 3sg and its corresponding zero-marking. In his Geschichte der indogermanischen Verbalflexion (1969), Watkins goes as far as to remark that this phenomenon, a characteristic feature of Proto-Indo-European, "ist an sich weder sehr bemerkenswert noch interessant. Vom Gesichtspunkt der Sprachtypologie aus gesehen wird rekonstruiertes Indogermanisch dadurch lediglich auf die Liste all der Sprachen verwiesen, die die gleiche Erscheinung zeigen. Diese Liste könnte sehr wohl Vertreter der meisten Sprachfamilien der Welt aufweisen" (1969: 18). The following examples can be added to the evidence collected by Benveniste (1946) and Watkins (1962): ${ }^{1}$

\begin{tabular}{|c|c|}
\hline $1 \mathrm{sg}$ & $\begin{array}{l}\text { PRESENT } \\
p u h u-\varnothing-n\end{array}$ \\
\hline $2 s g$ & $p u b u-\varnothing-t$ \\
\hline $3 \mathrm{sg}$ & pubī- $\varnothing-\varnothing$ \\
\hline
\end{tabular}

Finnish
I would like to thank the Alexander S. Onassis Public Benefit Foundation for bestowing the honour of a Category A1 fellowship on me.

${ }^{1}$ I use traditional terminology to refer to TA distinctions: imperfect = 'imperfective past', aorist $=$ 'perfective past' (cf. Holton, Mackridge \& Philippaki-Warburton 1997: 111). What is called 'perfect' in the Hebrew grammatical tradition is in fact a perfective past, but I hesitate to call it 'aorist' out of respect for this tradition (cf. Joüon \& Muraoka 1996: 354ff. for discussion). 
Finnish has a zero ending in the $3 \mathrm{sg}$ of the imperfect, and also in the present, where short stem-final vowels are lengthened, as in $p u b \bar{u}-\varnothing-\varnothing$ 's/he speaks' (Branch 1987: 603f.). Biblical Hebrew has a zero ending in the masculine 3sg of the perfect, here quoted in the so-called 'simple conjugation' traditionally labeled qal 'light': qätal- $\varnothing$ 'he (has) killed' (Joüon \& Muraoka 1996: 658). Obviously, the examples just quoted only illustrate the pervasiveness of zero marking in the $3 \mathrm{sg}$, not the analogical remodelling of the verbal paradigm in its entirety.

Watkins' Law is acknowledged as such in many textbooks and handbooks of historical linguistics, e.g. Arlotto (1972: 156), Joseph (1998: 365), Hock (2003: 446), Trask (2000: 366), Trask \& Millar (2007: 167). Collinge lists it among the 'minor' laws of Indo-European (1985: 239f.). Hock, referring to Watkins' original statement without using the term 'Law' (1991: 668), considers the evidence "rather meagre" (1991: 222). Let's see what Greek has to offer in this respect.

Joseph (1997: 207f.) discusses a rather spectacular instance of Watkins' Law from Ancient Greek. The synchronically defective verb $\bar{e}-m i$ ' say' is attested in the $1 \mathrm{sg}$ and $3 \mathrm{sg}$ of the present and imperfect only:

$\begin{array}{lll} & \text { PRESENT } & \text { IMPERFECT } \\ 1 \mathrm{sg} & \bar{e}-m i & \overline{\bar{e}}-n \\ 3 \mathrm{sg} & \bar{e}-s i & \bar{e}-\varnothing\end{array}$

Etymologically, only the $3 \mathrm{sg}$ of the imperfect is old: Proto-Indo-European ${ }^{*} H_{l} \hat{e}-H_{l} e \hat{g}-t$ 's/he said' developed into Proto-Greek *ẽ $g-t$, which became $\bar{e}-\varnothing$ through regular deletion of word-final /t/ and /g/ (Rix 1976: 204). ${ }^{2}$ The $1 \mathrm{sg}$ should have been ${ }^{*} \bar{e} g-a$, from Proto-Indo-European ${ }^{*} H_{l} \hat{e}-H_{l} e \hat{g}-m$, cf. Homeric $\bar{e}-a$, Vedic às-am, from Proto-Indo-European ${ }^{*} H_{l} \dot{e}-H_{1} e s-m$ 'I was'. The attested form $\bar{e}-n$ has been remodeled on the analogy of the semantically closely related $\operatorname{verb} p^{b} \bar{a}-m i$, Ionic-Attic $p^{b} \bar{e}-m i$, cf. Armenian $b a-m$, from Proto-Indo-European * $b^{b} e^{\prime} H_{2}-m i$ 'I say' (Rix 1976: 250):

$\begin{array}{lll} & \text { PRESENT } & \text { Imperfect } \\ 1 \mathrm{sg} & p^{h} \bar{e}-m i & \dot{e}-p^{b} \bar{e}-n \\ 3 \mathrm{sg} & p^{p} \bar{e}-s i & \bar{e}-p^{b} \bar{e}-\varnothing\end{array}$

${ }^{2}$ On the etymology of $\bar{e}-m i$ see Schwyzer (1939: 678), Chantraine (1968-80: 413), Rix (1976: 204). 
Joseph's conclusion that the verb $\bar{e}-m i$ "is entirely built up with a single form as a starting point" (1997: 207) is correct, but only if one takes into to account the analogy $\dot{e}-p^{h} \bar{e}-\varnothing: e^{-}-p^{h} \bar{e}-n \rightarrow \bar{e}-\varnothing: \tilde{e}-n$, and then $p^{h} \bar{e}-m i: p^{h} \bar{e}-s i \rightarrow \bar{e}-m i:$ $\bar{e}-s i$ (Schwyzer 1939: 678). Obviously, the analogy works beyond $\bar{e}^{h} p^{h} \bar{e}-\varnothing$ : $\dot{e}-p^{h} \bar{e}-n$ in that the so-called 'secondary' endings $1 \mathrm{sg}-n$, 3sg $-\varnothing$, which are in fact 'unmarked' and so actually 'primary' (Sihler 1995: 453; cf. Hock 1991: 219), are to be found in other paradigms as well, e.g. root aorists such as

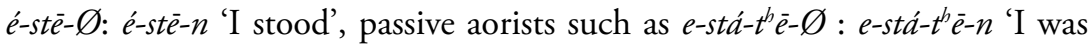
made to stand', from ' ${ }^{h}$-ste- $-m i$ 'make to stand'. The Modern Greek aorist passive paradigm is built on the $3 \mathrm{sg}$ of such aorists (and ultimately on a contamination of perfect and aorist forms, cf. Horrocks 1997: 232f.), e.g. stá$\theta i-k-e$ from earlier $e-s t a ́-t^{h} \bar{e}-\varnothing$.

Another case for the workings of Watkins' Law in Ancient Greek is provided by Hock (1991: 219f.) and Sihler (1995: 461f.), who argue against the traditional reconstruction of the 2-3sg of the thematic present (e.g. Rix 1976: 251) on the basis of the pivotal position of the $3 \mathrm{sg}$ in analogical restructurings (the details of the relationship between the Proto-Indo-European and Proto-Greek forms are disputed, but irrelevant to our discussion). The example used by both is the verb $p^{h}$ ér-ó 'I carry':

$\begin{array}{ll} & \text { PRESENT } \\ 2 \mathrm{sg} & { }^{*} p^{b} e ́ r-e-{ }^{h} i \\ 3 \mathrm{sg} & { }^{*} p^{h} e ́ r-e-i\end{array}$

Proto-Greek

$\begin{array}{ll}\text { IMPERFECT } & \text { PRESENT } \\ \dot{e}-p^{h} e r-e-s & p^{h} e ́ r-e i-s \\ \dot{e}-p^{h} e r-e-\varnothing & p^{h} e ́ r-e i-\varnothing\end{array}$

IMPERFECT

$e ́-p^{h} e r-e-s$

$e ́-p^{h} e r-e-\varnothing$

The explanation is that the $-s$ in $p^{h}$ ér-ei-s was added to disambiguate the homophonous 2-3sg forms $p^{h}$ ér-ei- $\varnothing$, after the loss of intervocalic $/ \mathrm{h} /$ in the $2 s g$, on the basis of the proportionality between $e^{-}-p^{h} e r-e-\varnothing: e^{\prime}-p^{h} e r-e-s$, where the $-s$ is the original 'secondary' ending inherited from Proto-Indo-European, viz. $p^{h} e^{\prime}-e i-\varnothing: \mathrm{X}=p^{h} e^{\prime}-e i-s .^{3}$

Watkins' Law has also been shown to be operative in Modern Greek. Thumb (1910: 162f.) points out that in many modern dialects (especially, but not exclusively, the Peloponnesian) the 1-3sg of contract (oxytone) verbs like rotó 'I ask' show the addition of the productive 1-3sg endings $-o,-i s,-i$ to the old 3 sg form (e)rotá, still preserved elsewhere in Greece. ${ }^{4}$ This is an example of

${ }^{3}$ For critical discussion of the traditional reconstruction see Rix (1976: 251), Hock (1991: 220), Sihler (1995: 462).

${ }^{4}$ Cf. Householder \& Nagy (1972: 44), Joseph (1980: 183). In Standard Modern Greek, 1 sg rotá-o, $3 \mathrm{sg}$ rotá- $i$ are used as alternatives to the contract (oxytone) forms 1 sg rotó, 3 sg rotá (Holton, Mackridge \& Philippaki-Warburton 1997: 127f.). 
what Watkins calls "the final possible transformation of a paradigm built out of a 3sg. form with zero ending" (1962: 95). On the analogy of non-contract (paroxytone) verbs like fér-o 'I carry' a new paradigm is built on the basis of the original $3 \mathrm{sg}$ form with zero ending:

$\begin{array}{lll} & \text { PRESENT } & \text { PRESENT } \\ 1 \mathrm{sg} & \text { fér-o } & \text { rotá-o } \\ 2 \mathrm{sg} & \text { fér-is }^{\prime} & \text { rotá-is } \\ 3 \mathrm{sg} & \text { fér }^{-i} & \text { rotá-i }\end{array}$

Joseph (1980) invokes Watkins' Law to explain the development of the Modern Greek preterite endings, particularly the generalization of the 'strong' (thematic) 2sg ending - $e-s$ at the expense of the 'weak' (athematic) 2 sg ending -a-s, e.g. modern $e ́-\gamma r a p-s-e-s$ for ancient é-grap-s-a-s 'you wrote'. This might seem at first sight remarkable, as the $a$-endings have been generalized in the rest of the paradigm, e.g. modern $\dot{e}-f i \gamma-a-n$ for ancient $\dot{e}-p^{b} y g-o-n$ 'they went off'. As Joseph points out, the influence of the $3 \mathrm{sg}$ ending has been responsible for the retention of the 2 sg ending in two ways: "through an analogical connection made internally within the preterite system [...] and through proportional analogies made between present and preterite endings" (1980: 183):

(7) Standard Modern Greek

$\begin{array}{llll} & \text { PRESENT } & \text { IMPERFECT } & \text { AORIST } \\ 1 \mathrm{sg} & \gamma r a ́ f-o & e ́-\gamma r a ́ f-a & e ́-\gamma r a ́ p-s-a \\ 2 \mathrm{sg} & \gamma r a ́ f-i s & e ́-\gamma r a ́ f-e s & e ́-\gamma r a ́ p-s-e s \\ 3 \mathrm{sg} & \gamma r a ́ f-i & e ́-\gamma r a ́ f-e & e ́-\gamma r a ́ p-s-e\end{array}$

Joseph's view of Watkins' Law is a novel interpretation of the principle: "Watkins' Law should be viewed both as a negative force by which certain possible changes might be prevented and by which paradigms might to some extent be kept intact in an older state, and also as a positive force by which new paradigms are shaped" (1980: 183f.). Elsewhere, he reminds us that "as with other proposed principles, "Watkins' Law" is also just a tendency" (1998: 365). In other words, even if Watkins' Law has been shown to have crosslinguistic validity, that does not imply that the process is exceptionless-but then which 'law' is exceptionless in historical linguistics? ${ }^{5}$ It is nevertheless

5 Potential counterexamples in Modern Greek are discussed by Joseph (1980: 183f.; 1998: 352; 2006: 177ff.). 
clear that Watkins' Law has been pervasive in its effect at all periods in the history of Greek. In the next sections I present further evidence on the workings of Watkins' Law in Asia Minor Greek.

\section{The Copula and the Medio-Passive Imperfect in Cappadocian and Bithynian}

In several Asia Minor Greek dialects, the inflection of the copula is very remarkable, especially in the imperfect. In Cappadocia, for instance, the Modern Greek type is found only at Delmesó, Araván and Ghúrzono (Dawkins 1916: 148; Phosteris \& Kesisoglou 1960: 152f.): ${ }^{6}$

$\begin{array}{llll} & \text { PrEs. } & & \text { IMPF. } \\ 1 \mathrm{sg} & \text { (i)-me } & & \text { (i)-mun } \\ 2 \mathrm{sg} & \text { (i)-se } & & \text { (i)-sun } \\ 3 \mathrm{sg} & \text { (i)-ne } & \text { én } & \text { (i)-tun } \\ 1 \mathrm{pl} & \text { (i)-meste } & & \text { (i)-meste } \\ 2 \mathrm{pl} & \text { (i)-ste } & \text { (i)-ste } \\ 3 \mathrm{pl} & \text { (i)-nde } & \text { (i)-san }\end{array}$

The forms without initial $i$-are enclitic. The present 3sg én (substantive) and the imperfect 3pl i-san are ancient forms (Brown 1983: 66; Horrocks 1997: 97). The present $3 \mathrm{pl} i$-nde has the ending of the $3 \mathrm{pl}$ of the medio-passive present inflection, which leaves the $3 \mathrm{sg} i$-ne as the odd one out. The other Cappadocian villages, however, have a very remarkable inflection in the imperfect. Compare, for instance, the following forms from Anakú (Costakis 1964: 48):

(9) Anakú

\begin{tabular}{|c|c|c|c|c|c|}
\hline & Present & & IMPERFECT & & \\
\hline $1 s$ & (i)-me & & (i)-to-me & (i)-ta-me & (i) - to-ma \\
\hline & (i) $-s e$ & & (i) -to-se & (i) $-t a-s e$ & (i) -to-sa \\
\hline & (i)-ne & $e ́ n(e)$ & (i) $-\operatorname{ton}(e)$ & (i) $-\tan (e)$ & \\
\hline $1 \mathrm{nl}$ & (i)-meste & & (i)-to-meste & (i)-ta-meste & \\
\hline & (i)-ste & & (i)-to-ste & (i)-ta-ste & \\
\hline & (i) -ne & (i)-nde & (i)-ton-(de) & (i) $-\tan -(d e)$ & (i)-san-(de) \\
\hline
\end{tabular}

${ }^{6}$ Dawkins (1916: 148) only quotes the enclitic forms of the present from Araván and those of the imperfect from its twin village, Ghúrzono. 
The forms with active endings (as in the passive aorist), viz. 1sg (i)-to-ma, $2 \mathrm{sg}$ (i)-to-sa, $3 \mathrm{pl}$ (i)-san-(de), were no longer in current use at the time of Costakis' fieldwork (1964: 48). The two other imperfect paradigms, one based on $3 \mathrm{sg}$ (i)-ton(e), the other on 3sg (i)-tan(e), have the same endings as the present in the 1-2sg, the 1-2 pl and, optionally, in the $3 \mathrm{pl}$. Note that the segmentation of the forms is at this stage still tentative!

The same inflection is found in the medio-passive imperfect, where the endings are again identical with those of the medio-passive present. The inflection has survived in Mišótika, the transplanted dialect of Mistí which is still spoken in several villages in Central and Northern Greece (Janse \& Papazachariou, forthcoming). The following examples represent the Mišótika forms of ci-me 'I am' (Kostakis 1977: 584, passim; Kotsanidis 2006: 231), ${ }^{7}$ from Byzantine Greek $\kappa \varepsilon^{i}-\mu \alpha$, here contrasted with the equivalent paradigm from Floitá (Dawkins 1916: 142): ${ }^{8}$

\begin{tabular}{|c|c|c|c|c|}
\hline $1 \mathrm{sg}$ & $\begin{array}{l}\text { Pass. Pres. } \\
\text { ci-me }\end{array}$ & $\begin{array}{l}\text { PASs. IMPF. } \\
\text { có-to-me }\end{array}$ & $\begin{array}{l}\text { Pass. Pres. } \\
t t_{s} i-m i\end{array}$ & $\begin{array}{l}\text { PASs. IMPF. } \\
\text { tšó-ठu-mi }\end{array}$ \\
\hline $2 s g$ & $c i-s e$ & có-to-se & $t s i-s i$ & tšó-ðu-si \\
\hline & ci-te & có-ton $(e)$ & $t s ̌ i-\partial i$ & tšó-ðun \\
\hline 10 & ci-meste & có-to-meste & tši-misti & $t t^{v o ́}-\partial u-m i s t i$ \\
\hline 1 & ci-ste & có-to-ste & $t s ̌ i-t i^{9}$ & $t s^{v} o ́-\partial u-t i^{9}$ \\
\hline $3 \mathrm{pl}$ & ci-nde & $\operatorname{có}-\tan (e)$ & $t s ̌ i-n d i$ & tšó-ðan \\
\hline
\end{tabular}

In some villages, e.g. Sílata (Dawkins 1916: 142), the $a$ has been generalized throughout the paradigm, whereas at Ulağáç the $o$ is used in the singular, whereas the $a$ occurs in the plural (Kesisoglou 1951: 42f.): ${ }^{10}$

7 On the phonology and phonetics of Mišótika see Kostakis (1990): raising of unstressed $e \rightarrow i, o \rightarrow u$ (1990: 176), intervocalic voicing and subsequent spirantization of $t \rightarrow d \rightarrow \gamma$ (1990: 184), and palatalization of $c \rightarrow t s$ (1990: 186) explain such forms as 3sg cóto-me $\rightarrow$ tšódu-mi $\rightarrow$ tšóðu-mi. Intervocalic /ð/, like any other fricative, tends to be dropped in casual speech (1990: 181), hence forms like 3sg tšóðun $\rightarrow$ tšóun, which are very common. The variation is of course irrelevant for our present purposes.

8 The texts from Floitá collected by Dawkins present the following forms: ci-nde (1916: 424), cóto-me (1916: 430 bis), cóton \# V (1916: 436, 440), cóton \# C (1916: 414, 430, 436), cótone \# C (1916: 414), cótone \# V (1916: 410, 414, 432). For the rest of the present inflection we have to rely on Dawkins (1916: 608). The additional $e$ attached to the $3 \mathrm{sg}$ and $3 \mathrm{pl}$ is optional, here as elsewhere.

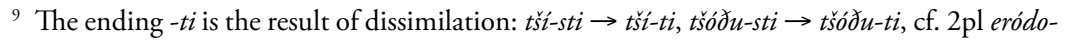
sti 'you came' (Dawkins 1916: 142). For similar cases of dissimilation in Cappadocian see Dawkins (1916: 84, 131, 137).

${ }_{10}$ The paradigm from Sílata is quoted in its entirety by Dawkins (1916: 142): ér(x)u-ta-me. The reduction of the cluster $r x \rightarrow r$ is common in ér $x$-u-me 'I come' (Dawkins 1916: 83). 


$\begin{array}{lll}\text { (11) } & \text { Sílata } & \text { Ulağáç } \\ & \text { PASs. IMPF. } & \text { PAss. IMPF. } \\ 1 \mathrm{sg} & \text { erú-ta-me } & \text { éro-to-me } \\ 2 \mathrm{sg} & \text { erú-ta-se } & \text { éro-to-se } \\ 3 \mathrm{sg} & \text { erú-tan } & \text { éro-ton } \\ 1 \mathrm{pl} & \text { erú-ta-meste } & \text { éro-ta-misti }{ }^{11} \\ 2 \mathrm{pl} & \text { erú-ta-ste } & \text { éro-ta-tte } \\ 3 \mathrm{pl} & \text { erú-ta-nde } & \text { éro-ta-nde }\end{array}$

Finally, it should be noted that Dawkins (1916: 143) records similar forms from Bithynian, a dialect unrelated to Cappadocian (1916: 37):

$\begin{array}{lll} & \text { PASs. IMPF. } & \text { IMPF. (CopUla) } \\ 1 \mathrm{sg} & \text { érxu-da-me } & \text { (i)-da-me } \\ 2 \mathrm{sg} & \text { érxu-da-se } & (\text { i)-da-se } \\ 3 \mathrm{sg} & \text { érxu-dan } & \text { (i)-dan } \\ 1 \mathrm{pl} & \text { érxu-da-maste } & (\text { i)-da-maste } \\ 2 \mathrm{pl} & \text { érxu-da-ste } & \text { (i)-da-saste } \\ 3 \mathrm{pl} & \text { érxu-dan-an } & \text { (i)-dan-an }\end{array}$

\section{Watkins' Law: The Turkish Connection}

The interpretation of the forms presented in the previous section is due to Dawkins (1916: 143), who concluded that the paradigm of the medio-passive imperfect is built on the $3 \mathrm{sg}$, with the endings of the medio-passive present $1 \mathrm{sg}-m e, 2 \mathrm{sg}-\mathrm{se}, 1 \mathrm{pl}-m e s t e, 2 \mathrm{pl}$-ste reinterpreted as personal endings tout court. The $3 \mathrm{sg}$ was reinterpreted as a stem with a zero ending, and the rest of the paradigm is built on this new stem. According to Dawkins, the final $-n$ of the $3 \mathrm{sg}$ was assimilated and the $o$ or $a$ generalized in accordance with the $3 \mathrm{sg}$ (1916: 143). That this interpretation must be correct, is shown by paradigms

11 The accent in the $1 \mathrm{pl}$ éro-ta-misti is on the fifth-last syllable, which probably explains the raising of $e \rightarrow i$, which occurs sporadically at Ulağáç (Kesisoglou 1951: 11). The form éro-tamisti is recorded by Dawkins (1916: 143), but not by Kesisoglou, who quotes the present éromiste (1951: 42).

12 The ending of the $2 \mathrm{pl}$ of the medio-passive imperfect - tte instead of -ste at Ulağáç is identical with the ending of the 2pl of the medio-passive present, cf. ér-e-tte (Kesisoglou 1951: 42). Dawkins (1916: 142f.), however, distinguishes -tte (present) from -tde (imperfect), which doesn't seem to make much sense, as the rest of the paradigm is clearly based on the present. If -tde is correct (there are no recorded examples in Dawkins' texts), the -de could have been taken from the 3pl (?).

${ }^{13}$ Dawkins quotes 3pl éro-tan (1916: 143) versus šíkó-ta-nde 'they stood up' (1916: 142). Kesisoglou records three instances of éro-ta-nde (1951: 43, 136 bis). 
such as the following from Aksó, where the final $-n$ of the $3 \mathrm{sg}$ is preserved throughout (Mavrochalyvidis \& Kesisoglou 1960: 58): ${ }^{14}$

$$
\text { Aksó }
$$

\begin{tabular}{|c|c|c|c|}
\hline & Present & & IMPERFECT \\
\hline $1 s g$ & (in)-me & & (i)-çton-me \\
\hline $2 \mathrm{sg}$ & (in) $-s e$ & & (i) -çton-se \\
\hline $3 \mathrm{sg}$ & (i) $-n(e)$ & én & (i) -çton \\
\hline $1 \mathrm{pl}$ & (in)-meste & & (i)-çton-meste \\
\hline $2 \mathrm{pl}$ & (in)-ste & & (i)-çton-ste \\
\hline $3 \mathrm{p}$ & (i)-nde & & (i) $-c ̧ \tan$ \\
\hline
\end{tabular}

Looking at the paradigms just quoted, it is probably more correct to say that it is the enclitic forms of the copula $i$-me that have been reinterpreted as personal endings tout court, at least for the medio-passive inflections. This is where the Turkish connection comes in, as already noted by Dawkins (1916: 143). Turkish is a canonical Watkins-type language, where the $3 \mathrm{sg}$ has a zero ending around which verbal paradigms are built by the agglutination of personal suffixes (Kornfilt 1997: 382; Lewis 2000: 96; Göksel \& Kerslake 2005: 87ff.). ${ }^{15}$ The socalled 'type I' personal suffixes coincide with the forms of the present of the verb 'to be' and are very similar to the personal suffixes attached to nouns (Kornfilt 1997: 382ff.; Lewis 2000: 37, 93; Göksel \& Kerslake 2005: 69, 88f.). To appreciate the similarity between the Turkish and Cappadocian paradigms, I now contrast the enclitic forms of a typical Cappadocian copula such as one of the Anakú types in (9) with their Turkish counterparts in (14), using capital-letter vowels in the Turkish (here and throughout) to indicate harmonizing vowels:

Anakú

$\begin{array}{lllll} & \text { PRESENT } & \text { IMPERFECT } & \text { PRESENT } & \text { IMPERFECT } \\ 1 \mathrm{sg} & -m e & -(i)-\text { to-me } & -I m & -(i)-d I-m \\ 2 \mathrm{sg} & -s e & -(i)-t o-s e & -s I n & -(i)-d I-n \\ 3 \mathrm{sg} & -n e & -(i)-\text { ton- } \varnothing & -\varnothing & -(i)-d I-\varnothing \\ 1 \mathrm{pl} & -m e s t e & -(i)-\text { to-meste } & -I z & -(i)-d I-k \\ 2 \mathrm{pl} & -s t e & -(i)-t o-s t e & -s I n I z & -(i)-d I-n I z \\ 3 \mathrm{pl} & -n d e & -(i)-t o-n d e & -l E r & -(i)-d I-l E r\end{array}$

${ }^{14}$ Dawkins (1916: 148) quotes forms like imperfect 1sg é-don-me, 2sg é-don-se, etc., but his texts only have $i$-tone (1916: 396). Mavrochalyvidis \& Kesisioglou present both paradigms in their entirety (1960: 58), with copious examples (1960: 255f.), and discuss the development of the palatal fricative $c$ in forms such as imperfect 3sg içton on the analogy of the enclitic form -iton $\rightarrow$-jton $\rightarrow$-çton, as a result of synizesis (1960: 7). Dawkins quotes similar forms from Ghúrzono (1916: 63) and Aksó (1916: 64).

15 Not surprisingly, Turkish is among the languages quoted (with examples) by Watkins (1962: 91). 
What we have here is a clear case of a contact-induced analogical remodeling of the entire medio-passive paradigm as an agglutinative inflection built around the 3sg in accordance with Watkins' Law. Note that the existence of resistant $3 \mathrm{pl}$ forms such as (i)-ton, (i)-tan, (i)-san from Anakú (9), có-tan(e) from Floitá (10), tšó-ðun from Mistí (10), or (i)-çtan from Aksó (13) are not necessarily counterexamples, neither to Watkins' Law as such, nor to the interpretation of such paradigms as agglutinative. The resistance of $3 \mathrm{sg}$ and $3 \mathrm{pl}$ forms to analogical developments is well attested (Hock 1991: 222; cf. Watkins 1962: 94). The 'irregular' 3pl sq in the Polish paradigm quoted in (1) is in this respect similar to non-agglutinative $3 \mathrm{pl}$ forms such as (i)-tan. Moreover, as Dawkins notes: "The 3rd pl. has been left alone, as being formed in Turkish by adding to the 3rd sg. not a characteristic personal ending, but merely the -ler, -lar of general plurality" (1916: 143).

A possible counterargument to the proposed analysis is that the enclitic form of the present $3 \mathrm{sg}$ is -ne and that this should be taken as the generalized $3 \mathrm{sg}$ ending in the entire medio-passive paradigm. As a matter of fact, forms such as có-tone from Floitá (10) are attested and could be taken as evidence for a different segmentation, e.g. có-to-ne. Apart from begging the question of the origin of the 'suffix' -to-, it should be noted that this additional -e, if it occurs at all, is almost everywhere optional. Compare the occurrence of cóton vs. cótone, both before vowels and before consonants, at Floitá (10). Secondly, it ignores the paradigms where the $-n$ is retained throughout, such as the following examples from Aksó (Dawkins 1916: 142; Mavrochalyvidis \& Kesisoglou 1960: 71f., 256):

Aksó

$\begin{array}{lll} & \text { IMPERFECT } & \text { IMPERFECT } \\ 1 \mathrm{sg} & \text { erú-ton-me } & \text { có-ton-me } \\ 2 \mathrm{sg} & \text { erú-ton-se } & \text { có-ton-se } \\ 3 \mathrm{sg} & \text { erú-ton- } \varnothing & \text { có-ton- } \varnothing \\ 1 \mathrm{pl} & \text { erú-ton-meste } & \text { có-ton-meste } \\ 2 \mathrm{pl} & \text { erú-ton-ste } & \text { có-ton-ste } \\ 3 \mathrm{pl} & \text { erú-tan- } \varnothing & \text { có-tan- } \varnothing\end{array}$

It may be noted that Dawkins (1916: 142) quotes 3sg erú-done (sic) from Aksó, as if the final /e/ were obligatory, whereas the only example in his corpus is erxú-ton (sic) (1916: 398). Mavrochalyvidis \& Kesisoglou record erú-ton throughout, both before vowels and before consonants (1960: 84, 186, 208, 216). Similarly, có-ton is recorded three times by Mavrochalyvidis \& Kesisoglou (1916: 200), có-tan twice by Dawkins (1916: 400, 402). 
Finally, it should be noted that the paradigm at Ulağáç is different from the others in that it has $o$ in the singular and $a$ in the plural (11). This may be explained as analogy from the 3pl: 3sg éro-ton- $\varnothing: 1$ sg éro-to-me :: $3 \mathrm{pl}$ érotan- $\varnothing: 1 \mathrm{pl}$ éro-ta-misti. It is also possible this a was felt to be part of the plural, as in the combination of adjective plus enclitic copula, e.g. kaló-tun 'was good', pl. kalá-tan from Semenderé (Dawkins 1916: 148).

\section{Double endings in Agglutinative Inflections?}

I conclude with Dawkins' record of a very unusual phenomenon in the Cappadocian dialect of Semenderé, of which he says: "The extremes to which the Turkish influence has gone may be seen from the paradigms of the noun and still more of the verb" (1916: 18). The phenomenon referred to is the addition, in the 1-2pl of the medio-passive imperfect and present copula, of the Turkish type II (past) personal suffixes $1 \mathrm{pl}-k$ and $2 \mathrm{pl}-n I z$ (Kornfilt 1997: 382; Lewis 2000: 105; Göksel \& Kerslake 2005: 88) to the Greek endings. ${ }^{16}$ The examples quoted by Dawkins (1916: 144, 148) are the paradigms of the imperfect inflection of $c e ́-m i$ 'I am' and in-mi 'I am': ${ }^{17}$

$\begin{array}{lll}\text { (16) } & \text { Semenderé } & \\ & \text { IMPERFECT } & \text { IMPERFECT } \\ 1 \mathrm{sg} & \text { cé-tun-mi } & \text { (i)-tun-mi } \\ 2 \mathrm{sg} & \text { cé-tun-si } & \text { (i)-tun-si } \\ 3 \mathrm{sg} & \text { cé-tun-Ø } & \text { (i)-tun- } \varnothing \\ 1 \mathrm{pl} & \text { cé-tun-misti-c } & \text { (i)-tun-misti-c } \\ 2 \mathrm{pl} & \text { cé-tun-sti-niz } & \text { (i)-tun-sti-niz } \\ 3 \mathrm{pl} & \text { cé-tan(-di) } & \text { (i)-tan(-di) }\end{array}$

The same phenomenon is found in Lycaonian (Sílli dialect) and again restricted to the 1-2pl, though optionally. Since they are only used in the present, not in the imperfect, the Turkish personal present or type I endings -Iz and -sInIz are used according to Dawkins (1916: 59), although they rather look like conflations of type I and type II personal suffixes. The examples quoted by Dawkins are érx-u-mu 'I go' (1916: 58) and i-mu 'I am' (1916: 61): ${ }^{18}$

16 Thomason and Kaufman's (1988: 219) representation of these examples is confusing in that they do not mention the fact that the Turkish personal suffixes are combined with the Greek endings.

17 The dialect of Semenderé is characterized by vowel raising (Dawkins 1916: 64).

18 The dialect of Sílli is characterized by vowel raising (Dawkins 1916: 42) and palatalization (1916: 45). 
Sílli

\begin{tabular}{|c|c|c|}
\hline & Present & Present \\
\hline lsg & érx-u-mu & $i-m u$ \\
\hline gg & ér š-i-si(s) & $i-s u$ \\
\hline & $e ́ r s-i-t i$ & éni $i$ \\
\hline & érx-u-misti(-ñiz) & $i$-misti(-ñiz) \\
\hline & érš-i-sti(-ñiz) & $i-s t i(-\tilde{n} i z)$ \\
\hline & $e ́ r x-u-n d i$ & inu \\
\hline
\end{tabular}

Myers-Scotton briefly discusses the examples just quoted (without actually quoting them herself), i.e. the intrusion of "alien system morphemes", as resulting from a "Matrix Language turnover that did not go to completion" (2002: 245). The result is a bilingual mixed language or, in Myers-Scotton's terminology (2002: 246), a "split language". There can be no doubt that Cappadocian (and probably also Lycaonian) is an instance of such a bilingual mixed language. ${ }^{19}$ But what exactly has happened in the 1-2pl forms in (16) and (17)? Why is there no trace of similar forms in the singular, e.g. 1sg *itun-

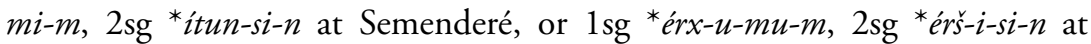
Sílli?

I think the solution to the problem is to be found in the sound shape of the personal endings $1 \mathrm{pl}-$ misti, $2 \mathrm{pl}-s t$. The former, especially, is very similar to the Turkish suffix combination $-m I_{g}-t I$, which is used to derive the pluperfect (Lewis 2000: 123; Göksel \& Kerslake 2005: 84). Obviously, there is both an aspectual and a temporal difference between the Cappadocian imperfect and the Turkish pluperfect, so the only possible explanation is that the formal similarity of -misti to $-m I_{\xi}-t I$ must have had some kind of triggering effect in that it has served as a (sub- or unconscious) stimulus to trigger the Turkish endings. The triggering effect must have spread from the $1 \mathrm{pl}$ to $2 \mathrm{pl}$, where the - sti only bears a partial resemblance to $-m I_{\xi}-t I$. That it must have been a sub- or

(18) Semenderé

$\begin{array}{lll} & \text { PRESENT } & \text { IMPERFECT } \\ 1 \mathrm{sg} & \text { aéru-mi } & \text { aéru-tun-mi } \\ 2 \mathrm{sg} & \text { aéru-si } & \text { aéru-tun-si } \\ 3 \mathrm{sg} & \text { aéru-ti } & \text { aéru-tun(i) } \\ 1 \mathrm{pl} & \text { aéru-misti-c } & \text { aéru-tun-misti-c } \\ 2 \mathrm{pl} & \text { aéru-sti-niz } & \text { aéru-tun-sti-niz } \\ 3 \mathrm{pl} & \text { aéru-ndi } & \text { aéru-tan(-di) }\end{array}$

${ }^{19}$ For a recent assessment see Winford (2005, especially p. 402ff.). 
unconscious process follows from the comparison of the present and imperfect inflections of the Semenderé equivalent of érx-u-me (Dawkins 1916: 144): ${ }^{20}$ In Lycaonian, something similar has happened, but in this case it is not entirely clear whether the ending -niz represents the Turkish type I personal suffixes $1 \mathrm{pl}-I z, 2 \mathrm{pl}-s I n I z$ or, in the case of the $2 \mathrm{pl}$, the type II personal suffix $-n I z$. It is quite well possible that the generalization of either the type I or type II personal endings suggested by the Semenderé and Sílli forms of the 1-2pl reflects a local Turkish phenomenon. In this respect it is significant that Kowalski records the generalization of $-k$ and especially $-n I z(-\eta I z)$ instead of $-s I n I z$ (-sIyIz), "namentlich in kleinasiatischen Mundarten" (1931: 1006). This would at least explain the occurrence of $-c$ in present forms like aéru-misti-c at Semenderé (10) and of -ñiz in forms like érx-u-misti-ñiz (9) at Sílli, the latter clearly being a conflation of $1 \mathrm{pl}-I z$ and $2 \mathrm{pl}-n I z$.

In the preceding section it was stated that there can be no doubt that Cappadocian (and probably also Lycaonian) is a bilingual mixed language in the sense of Thomason: "a language created by bilinguals, with major components drawn from each of the two languages in a contact situation" (2001: 259). A qualification is in order though. Cappadocian is a language without a written norm, even without a spoken norm. It is a dialect continuum in which "most [...] clearly retain enough inherited Greek grammar to count as Greek dialects in the full genetic sense; a few dialects may be close to or even over the border of nongenetic development" (Thomason \& Kaufman 1988: 94). It is neither clear how much inherited grammar is needed to count as a dialect in the full genetic sense, nor how much borrowed grammar is needed to count as a bilingual mixed language. There is no comprehensive typological description of the various Cappadocian dialects (or of Lycaonian, for that matter) to decide which is which.

What is clear, however, is that the Turkish element in both Cappadocian and Lycaonian (and probably also in Bithynian) is such that Thomason and Kaufman consider Asia Minor Greek as "an excellent example of heavy borrowing" (1988: 215). Winford, on the other hand, argues that the "mixture of the kind found in [...] Cappadocian" (2005: 421) is the result of both borrowing and imposition, "involving adaptation of Greek to Turkish, rather than the other way around" (2005: 409). The latter is probably the

20 The full paradigms are taken from Dawkins' unpublished notebook Arch.Z.Dawk. 28 (1) kept at the Taylor Institution Greek \& Slavonic Library in Oxford. I was able to study the archives as a Visiting Fellow of All Souls College (Michaelmas 2007). I would like to thank the Warden \& Fellows of All Souls College for bestowing the honour of a Visiting Fellowship on me. I would also like to thank the Rector and Fellows of Exeter College for granting me permission to publish the unpublished parts of the archives. 
case in the adaptation of Greek to Turkish inflectional patterns, as illustrated in section 2 .

The question is whether the Turkish endings in forms such as cé-tun-misti-c and cé-tun-sti-niz should be considered as an example of (heavy) borrowing. In the literature on language contact, a distinction is usually made between code-switching and borrowing, although there seems to be a consensus that the boundary between the two is necessarily fuzzy. ${ }^{21}$ It is often claimed that code-switching is triggered by what Clyne (1967) calls "homophonous diamorphs". ${ }^{22}$ The similarity in form between the Cappadocian and Lycaonian personal endings $1 \mathrm{pl}-m i s t i$ and $2 \mathrm{pl}-s t i$ and the Turkish temporal suffix $-m I_{s} t I$ must have triggered the switch to the Turkish personal suffixes $1 \mathrm{pl}-k$ and $2 \mathrm{pl}$ $-n I z$ in Cappadocian and $1-2 \mathrm{pl}-n I z$ in Lycaonian. It can hardly be accidental that the switch occurs only in two vowel-raising dialects (Semenderé and Sílli), not in others, where the endings are $1 \mathrm{pl}-$ meste, $2 \mathrm{pl}-$ ste.

If this interpretation is correct, which I think it is, then forms such as $c \dot{e}-$ tun-misti-c and cé-tun-sti-niz constitute a violation of Poplack's Free Morpheme Constraint: "Codes may be switched after any constituent provided that constituent is not a bound morpheme" (Poplack 1980: 585). Cases like düsü̈ndüz-u "I consider" from Malakopí, where the stem düsündü- is Turkish and the ending $-z u$ is Greek (cf. below), are instances of borrowing, not code-switching, because the stem has been fully integrated in the morphology of the Cappadocian verb (Janse 2001: 82f.). However, the case of cé-tun-misti-c and cé-tun-sti-niz is different, because the endings $-c$ and $-n i z$ are not at all integrated, but triggered, probably optionally, as in Lycaonian (9), by the homophonous diamorphs $-m i s t i /-m I_{s} t I$ and - sti I $-(m I)$ st $I$.

The conflation of formally, but not functionally identical elements is attested in other contact languages. Russenorsk, for instance, has one all-purpose preposition $p a$ which is clearly chosen because of the formal, but not functional, similarity between the Norwegian preposition $p a$ and the Russian preposition $p o$ (Hock 1991: 523; Winford 2003: 274). Sango has only one locational / temporal preposition, viz. nà, which has formal, but not functional, counterparts in Ngbandi and other Ubangian languages, and also in Kitúba, a Bantu-based contact language, and other Bantu languages in general (Pasch 1997: 248).

And, finally, the integration of Turkish verbs in Cappadocian is based on similar principles. A verb like düşün-mek 'to consider' is borrowed on the basis of the perfective (simple) or di-past (Lewis 2000: 128), which corresponds

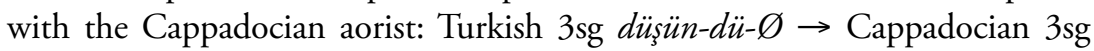

\footnotetext{
${ }^{21}$ Cf., e.g., Myers-Scotton (2002: 41), Thomason (2001: 133), Winford (2003: 108).

22 Cf. Broersma $\&$ de Bot (2006) for recent discussion of triggered code-switching with further references.
} 


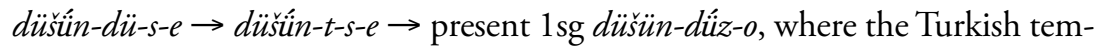
poral suffix $-d I$ is absorbed in the productive Greek suffix $-i z$ - on the basis of a reanalysis of the aorist dïsünn-t-s-e (Janse 2001: 82f.), cf. aorist 3sg fajji-s-e $\rightarrow$ fáj-s-e, present 1sg faj-iz-o 'I strike' (Dawkins 1916: 655). ${ }^{23}$

\section{Conclusion}

In this paper I have discussed the agglutinative inflection of the copula and the medio-passive imperfect in Cappadocian and Bithynian. I have shown how the Greek inflection was adapted to the Turkish inflection on the basis of the 3 sg in -ton. The phenomenon was interpreted as an instance Watkins' Law, which states that the $3 \mathrm{sg}$ occupies a pivotal position in the historical development of verbal paradigms in languages from different language families, including Indo-European and especially Altaic, and interestingly, with numerous examples throughout the history of Greek. The 3sg in -ton was reinterpreted as a stem with zero ending around which the rest of the paradigm was built. The personal endings have been shown to be identical with the enclitic forms of the copula on the analogy of the Turkish copula and hence extended from the medio-passive present to the imperfect. The $3 \mathrm{pl}$ is often left out of the new development, although in several dialects -nde is attached to the old ending.

In the Cappadocian dialect of Semenderé and the Lycaonian dialect of Silli, the $1-2 \mathrm{pl}$ of these agglutinative inflections is, probably optionally, characterized by the addition of the corresponding Turkish personal suffixes to the Greek ones. It has been argued that the former have been added to the latter because of the superficial formal similarity of the Greek personal suffixes with the corresponding Turkish temporal suffixes. The addition of the Turkish personal suffixes was interpreted as a case of triggered code-switching and hence as a violation of Poplack's Free Morpheme Constraint.

In sum, then, the development of agglutinative verbal paradigms in various Greek dialects of Asia Minor not only shows the effects of a pervasive tendency in the history of Greek (Watkins' Law) but also offers insights into two very general issues in language contact, namely the borrowing of grammatical patterns and the nature of bilingual code-switching.

23 The reality of the borrowing process is of course much more complicated, as aorist forms such as düšün-t-s-e may lead to different present formations, e.g. düsü̈n-düz-o (Aksó, Mavrochalyvidis \& Kesisoglou 1960: 131, 137), düšün-düz-u (Malakopí, Dawkins 1916: 674), djušun-díz-u (Mišótika, Kotsanidis 2006: 191), düšün-dó / düšün-dú (Ulağáç, Dawkins 1916: 674; Kesisoglou 1951: 112). 


\section{References}

Arlotto, Anthony. 1972. Introduction to historical linguistics. Boston: Houghton Mifflin.

Beekes, Robert S. P. 1988. A grammar of Gatha-Avestan. Leiden: Brill.

Benveniste, Emile. 1946. Structure des relations de personne dans le verbe. Bulletin de la Société de Linguistique de Paris 43: 1-12.

Branch, Michael. 1987. Finnish. In B. Comrie (ed.), The world's major languages, 593-617. London: Croom Helm.

Broersma, Mirjam and Kees de Bot. 2006. Triggered codeswitching: A corpus-based evaluation of the original triggering hypothesis and a new alternative. Bilingualism: Language and Cognition 9: 1-13.

Browning, Robert. 1983. Medieval and Modern Greek. 2nd ed. Cambridge: Cambridge University Press.

Chantraine, Pierre. 1968-80. Dictionnaire étymologique de la langue grecque. Paris: Klincksieck.

Clyne, Michael. 1967. Transference and triggering. The Hague: Mouton.

Collinge, Neville E. 1985. The laws of Indo-European. Amsterdam: John Benjamins.

Costakis, Athanase P. 1964. Le parler grec d'Anakou. Athènes: Centre d'Études d'Asie Mineure.

Dawkins, Richard M. 1916. Modern Greek in Asia Minor. Cambridge: Cambridge University Press.

Hock, Hans Henrich. 1991. Principles of historical linguistics. 2nd edn. Berlin: Mouton de Gruyter.

Hock, Hans Henrich. 2003. Analogical change. In B. D. Joseph and R. D. Janda (eds.), The handbook of historical linguistics, 441-460. Oxford: Blackwell.

Holton, David, Peter Mackridge and Irene Philippaki-Warburton. 1997. Greek: A comprehensive grammar of the modern language. London: Routledge.

Horrocks, Geoffrey. 1997. Greek: A history of the language and its speakers. London: Longman.

Householder, Fred and Gregory Nagy. 1972. Greek: A survey of recent work. The Hague: Mouton.

Janse, Mark. 2001. Cappadocian variables. In M. Janse, B. D. Joseph and A. Ralli (eds.), Proceedings of the First International Conference of Modern Greek Dialects and Linguistic Theory (Patras, Greece, Oct. 12-14, 2000), 79-88. Patras: University of Patras.

Janse, Mark. 2004. Animacy, definiteness and case in Cappadocian and other Asia Minor Greek dialects. Journal of Greek Linguistics 5: 3-26.

Janse, Mark and Dimitris Papazachariou. Forthcoming. Cappadocian (Asia Minor Greek). The resurrection of an 'extinct' language.

Johanson, Lars. 1998. The structure of Turkic. In L. Johanson and É. Á. Csató (eds.), The Turkic languages, 30-66. London: Routledge.

Joseph, Brian D. 1980. Watkins' Law and the Modern Greek preterite. Die Sprache 26: 179184.

Joseph, Brian D. 1997. On the linguistics of marginality: The centrality of the periphery. In G. Anderson [et al.] (eds.), Papers from the 33rd Regional Meeting of the Chicago Linguistic Society, 197-213. Chicago: Chicago Linguistic Society.

Joseph, Brian D. 1998. Diachronic morphology. In A. Spencer and A. M. Zwicky (eds.), The handbook of morphology, 351-373. Oxford: Blackwell.

Joseph, Brian D. 2006. On connections between personal pronouns and verbal endings in the Balkans. In R. Rothstein, E. Scatton and C. Townsend (eds.), Studia Caroliensia. Papers in linguistics and folklore in honor of Charles E. Gribble, 177-188. Bloomington: Slavica Publishers.

Joüon, Paul and Takamitsu Muraoka. 1996. A Grammar of Biblical Hebrew. Roma: Pontificio Istituto Biblico. 
Göksel, Aslı \& Celia Kerslake. 2005. Turkish. A comprehensive grammar. London: Routledge. Kesisoglou, I. I. 1951. To rlossikó iðioma tu Ulayáts. Athina: Kentro Mikrasiatikon Spoudon. Kornfilt, Jaklin. 1987. Turkish. London: Routledge.

Kostakis, Thanasis P. 1977. To Misti tis Kappadokias. Athina: Akadimia Athinon.

Kostakis, Thanasis P. 1990. Paratirísis sti fonitikí tu mistiótiku iðiómatos. Leksikoyrafikon Đeltion 7: 175-188.

Kotsanidis, Lazaros. 2006. To ylossikó iðioma tu Misti Kappadokias. Kilkis Paionias.

Kowalski, Tadeus. 1931. Osmanisch-Türkische Dialekte. In Enzyklopädie des Islam, IV, 9911010. Leiden: Brill.

Lewis, Geoffrey. 2000. Turkish grammar. 2nd ed. Oxford: Oxford University Press.

Lunt, Horace G. 2001. Old Church Slavonic grammar. 7th ed. Berlin: Mouton de Gruyter.

Mavrochalyvidis, G. and I. I. Kesisoglou. 1960. To rlossikó iðioma tis Aksú. Athina: Kentro Mikrasiatikon Spoudon.

Myers-Scotton, Carol. 2002. Contact linguistics. Bilingual encounters and grammatical outcomes. Oxford: Oxford University Press.

Pasch, Helma. 1997. Sango. In S. G. Thomason (ed.), Contact languages. A wider perspective, 209-270. Amsterdam: Benjamins.

Phosteris, D. and I. I. Kesisoglou. 1960. Leksilório tu Aravani. Athina: Kentro Mikrasiatikon Spoudon.

Poplack, Shana. 1980. 'Sometimes I'll start a sentence in Spanish y termino en español'. Toward a typology of code-switching. Linguistics 18: 581-618.

Rix, Helmut. 1976. Historische Grammatik des Griechischen. Laut-und Formenlehre. Darmstadt: Wissenschaftliche Buchgesellschaft.

Schwyzer, Eduard. 1939. Griechische Grammatik. Allgemeiner Teil, Lautlehre, Wortbildung, Flexion. München: Beck.

Stone, Gerald. 1987. Polish. In B. Comrie (ed.), The world's major languages, 348-366. London: Croom Helm.

Thomason, Sarah Grey. 2001. Language contact. An introduction. Edinburgh: Edinburgh University Press.

Thomason, Sarah Grey and Terrence Kaufman. 1988. Language contact, creolization, and genetic linguistics. Berkeley: University of California Press.

Thumb, Albert. 1910. Handbuck der neugriechischen Volkssprache. 2nd ed. Strassburg: Trübner.

Trask, R. Larry. 2000. The dictionary of historical and comparative linguistics. Edinburgh: Edinburgh University Press.

Trask, R. Larry and Robert McColl Millar. 2007. Historical linguistics. 2nd ed. London: Hodder Arnold.

Watkins, Calvert. 1962. Indo-European origins of the Celtic verb. vol. I. The sigmatic aorist. Dublin: Institute for Advanced Studies.

Windfuhr, Gernot L. 1987. Persian. In B. Comrie (ed.), The world's major languages, 523-546. London: Croom Helm.

Winford, Donald. 2003. An introduction to contact linguistics. Oxford: Blackwell Publishing.

Winford, Donald. 2005. Contact-induced changes. Classification and processes. Diachronica 22: 373-427. 